\title{
Management of Alternaria Leaf Spot of Lehsua through Plant Extracts and Fungicides
}

\author{
Sushila Choudhary ${ }^{1}$, R. P. Ghasolia ${ }^{1}$, Manisha Shivran ${ }^{1}$, \\ Ramniwas Yadav ${ }^{2}$ and Vinod Bairwa ${ }^{1}$ \\ ${ }^{1}$ Department of Plant Pathology, SKN College of Agriculture, Jobner, Jaipur-303329 \\ (SKNAU, Jobner), Rajasthan, India \\ ${ }^{2}$ Division of Plant Pathology, Rajasthan Agricultural Research Institute, Durgapura, Jaipur- \\ 302018, (SKNAU, Jobner), Rajasthan, India \\ *Corresponding author
}

\section{A B S T R A C T}

\section{Keywords}

Lehsua, Cordia myxa, Alternaria alternata, Management, Fungicides and Plant Extracts

Article Info

Accepted:

18 January 2020

Available Online:

10 February 2020
Lehsua (Cordia myxa Roxb.), also known as Lasoda, Gunda and Indian cherry, is a major fruit of the family Boraginaceae. To manage the disease, efficacy of plant extracts and fungicides were tested in vitro and in vivo against Alternaria alternata, causing Alternaria leaf spot. Among plant extracts, extracts of garlic $(10 \%)$ was found most effective in inhibiting mycelial growth $(83.33 \%)$ followed by neem $(79.03 \%)$ while in case of fungicides, tebuconazole + trifloxystrobin $(300 \mathrm{ppm})$ was found most effective in inhibiting cent per cent mycelial growth followed by hexaconazole $(95.56 \%)$. Individually, two sprays of garlic cloves extract $(10 \%)$ and tebuconazole + trifloxystrobin $(0.1 \%)$ at an interval of 20 days were found most effective in reducing disease intensity $(51.85 \%$ \& $80.84 \%$, respectively) over control.

\section{Introduction}

Lehsua (Cordia myxa Roxb.), also known as Lasoda, Gunda and Indian cherry, is a major fruit of the family Boraginaceae. It is native of north western India and distributed throughout the country in arid and semi arid regions especially in warmer regions up to $5,000 \mathrm{ft}$. It is a perennial, medium size tree with crooked stem attaining a height of nearly 3 to 4 meter and the total height of the tree comes to nearly 10 to 15 meter. Fruits of lehsua contain a good amount of protein (2\%), carbohydrate $(92 \%)$, fat $(2 \%)$ and also a good source of vitamins, calcium and minerals (Duhan et al., 1992 and Chandra et $a l .$, 1994). In India, it is mostly grown in Rajasthan, Punjab, Haryana, Uttar Pradesh, Madhya Pradesh, Assam, Maharashtra and Gujarat. In Rajasthan, lehsua is mainly cultivated in Ajmer (267 ha. area and 390 tonnes production) followed by Bhilwara, Sikar, Karauli, Dholpur, Jhalawar and SwaiMadhopur districts (Anonymous, 2017a). 
Lehsua is affected by foliar and post harvest diseases, which are responsible for their qualitative and quantitative deterioration. Alternaria leaf spot, die-back, gummosis, fruit rot, blue mould rot and Rhizopus rot have been observed from different locations of Jhalawar district of Rajasthan (Anonymous, 2017b). The symptoms of the disease initially were observed as brown or black coloured spots of indefinite size appearing on leaves with light brown or dark brown ringsand prominent bright yellow halo. Affected leaves further blighted and fall down (Maurya et al., 2016). The intensity of Alternaria leaf spot (Alternaria alternata) has been recorded in the range of 2.00-22.00 per cent in surveyed areas of Rajasthan (Anonymous, 2017b and 2018). Therefore, it was decided to control the disease through plant extracts and fungicides for improving quality and quantity of the produce.

\section{Materials and Methods}

\section{Efficacy of plant extracts (in vitro)}

The present investigation was carried out using five natural phyto-extracts viz. neem (Azadirachta indica), ginger (Zingiber officinale), garlic (Allium sativum), Alstonia (Alstonia scholaris) and datura (Datura stramonium) to see their antimycotic behaviour on the growth of Alternaria alternate on PDA following Poisoned Food Technique (Schmitzs, 1930) at 5 and 10 per cent concentrations.To get these concentrations, the required plant part was thoroughly washed with sterilized water and ground separately in electric grinder using equal amount of sterilized distilled water (i.e. 1:1 ratio, w/v). The mixture was squeezed with double layered sterilized cheese cloth. The extracts thus obtained were considered as of 100 per cent concentration.

Required quantity of each plant extract (i.e. stock solution) was mixed thoroughly in melted PDA, to get desired concentration (5 and $10 \%$ ), just before pouring in sterilized 9 $\mathrm{cm}$ diameter glass Petridishes and was allowed to solidify for 12 hours. Each plate was inoculated with $5 \mathrm{~mm}$ disc of mycelial bit taken with the help of sterilized cork borer from the periphery of 7 days old culture of $A$. alternata growing on PDA. The inoculated petridishes were incubated at $25 \pm 1^{\circ} \mathrm{C}$. Four petridishes were used for each treatment serving as four replications. A control was also maintained where medium was not supplemented with any plant extract. The experiment was conducted in completely Randomized Design (CRD). Colony diameter (two diagonals) was measured at $7^{\text {th }}$ day of incubation. Per cent growth inhibition was calculated by Vincent's (1947) formula as follows:

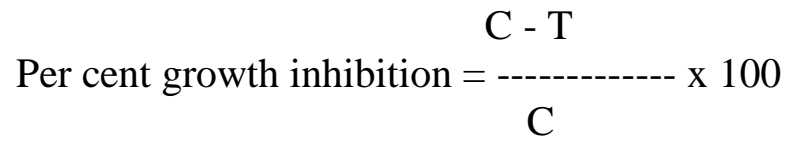

Where, $\mathrm{C}=$ diameter of the colony in check (average of both diagonals)

$\mathrm{T}=$ diameter of colony in treatment (average of both diagonals)

\section{Efficacy of plant extracts (in vivo)}

Extracts (10\%) of above five plants, were also tested in orchard by spraying twice at an interval of 20 days with four replications. First foliar spray of plant extracts was applied at the time of disease initiation $\left(3^{\text {rd }}\right.$ week of May). Per cent disease intensity (PDI) was recorded 20 days after of last spray as follows:

$$
\mathrm{PDI}=\frac{\text { Sum of all numerical ratings }}{\text { Total number of leaves observed } \mathrm{x} \text { Maximum disease grade }} \times 100
$$

\section{Efficacy of fungicides (in vitro)}

Efficacy of five systemic and non-systemic fungicides viz., tebuconazole + trifloxystrobin 
(Nativo), mancozeb (Indofil M 45), hexaconazole (Avone Plus) copper oxychloride (Blitox 50) and carbendazim + mancozeb (Companion) was assessed against mycelial growth of $A$. alternata by Poisoned Food Technique (Schmitzs, 1930). Three different concentrations viz., 100, 300 and 500 $\mathrm{ppm}$ of each fungicide was tested. Required quantity of each fungicide was added separately to sterilized medium, mixed thoroughly and poured in sterilized $9 \mathrm{~cm}$ diameter glass Petriplates and allowed to solidify. Four replications were maintained for each treatment. A control was also maintained where medium was not supplemented with any fungicides. Each plate was inoculated with $5 \mathrm{~mm}$ discs with the help of sterilized cork borer from the edge of the fungal culture and incubated at $25 \pm 1^{\circ} \mathrm{C}$ for 7 days. The linear growth of the test fungus was measured and per cent growth inhibition was calculated by vincent's (1947) formula.

\section{Efficacy of fungicides (in vivo)}

Above five systemic and non-systemic fungicides were also tested in orchard by spraying twice at an interval of 20 days with four replications. PDI was recorded 20 days after of last spray.

\section{Results and Discussion}

\section{Plant extracts}

Application of chemical fungicides are often cost prohibitive, impractical and hazardous to environment and human health. Keeping this in view, the need was felt for an alternative method to manage this disease in eco-friendly manner by using plant extracts. Plant extracts is of much significance in view of hazards caused by toxic chemicals or in a situation where pathogens develop resistance to fungi toxicants. The efficacy of five plant extracts was tested in vitro at two concentrations viz., 5 and 10 per cent against Alternaria alternata on PDA by Poisoned Food Technique (Table
1). Among five plant extracts, extract of garlic cloves was found most effective in inhibiting mycelial growth $(83.33 \%)$ of Alternaria alternata at 10 per cent concentration, followed by neem leaves $(79.03 \%)$ and ginger (74.08\%) over control. Extracts of datura $(52.44 \%)$ and Alstonia $(42.41 \%)$ were found least effective in inhibiting mycelial growth of Alternia alternate over control. All the concentrations (5 and 10\%) of all the tested plant extracts were found significantly superior with each other. Our observations in accordance with the findings of Singh and Majumdar (2001) who evaluated the efficacy of plant extracts viz., Allium sativum, Allium cepa, Curcuma longa, Zingiber officinale, Azadirachta indica, Datura stramonium and Ocimum sanctum against Alternaria alternata, causing fruit root of pomegranate. The results of Mistry (1992), Chattopadhyay (2001) and Choudhary et al., (2003) are also in accordance with our observations. They observed that extracts of garlic, neem and onion were found most effective against the mycelial growth of the Alternaria alternata in in vitro, causing leaf spot of papaya and tomato.

A perusal of data (Table 2) revealed that minimum disease intensity $(11.17 \%)$ was recorded with garlic cloves extract (10\%) by applying twice at 20 days interval followed by neem leaf extract $(12.52 \%)$ at 20 days after second spray and statistically found at par with each other. Leaf extract (10\%) of Alstonia was found least effective in reducing disease intensity $(28.10 \%)$ over control. Two sprays of garlic extract (10\%) at an interval of 20 days were found promising in reducing disease intensity in orchard of lehsua followed by neem leaves extract. Our findings are also following the results of Singh and Majumdar (2001), Panchali and Patil (2009) and Sallam and Kamal (2012). They reported effectiveness of garlic, neem and turmeric extract $(5-10 \%)$ in reducing disease intensity, caused by Alternaria spp. 
Table.1 Fungitoxicity of plant extracts against Alternaria alternata by poisoned food technique at $7^{\text {th }}$ day of incubation at $25 \pm 1{ }^{0} \mathrm{C}$

\begin{tabular}{|c|c|c|c|c|}
\hline \multirow[t]{2}{*}{$\begin{array}{l}\text { Common name } \\
\text { of plant }\end{array}$} & \multirow[t]{2}{*}{ Part used } & \multicolumn{2}{|c|}{$\begin{array}{l}\text { Per cent inhibition of mycelial growth } \\
\text { at different concentrations* }\end{array}$} & \multirow[t]{2}{*}{ Mean } \\
\hline & & $5 \%$ & $10 \%$ & \\
\hline \multirow[t]{2}{*}{ Garlic } & Clove & 75.55 & 83.33 & 79.44 \\
\hline & & $(60.37)$ & $(65.90)$ & $(63.04)$ \\
\hline \multirow[t]{2}{*}{ Neem } & Leaf & 71.25 & 79.03 & 75.14 \\
\hline & & $(57.58)$ & $(62.75)$ & $(60.09)$ \\
\hline \multirow[t]{2}{*}{ Ginger } & Rhizome & 56.25 & 74.08 & 65.16 \\
\hline & & $(48.59)$ & (59.39) & (53.83) \\
\hline \multirow[t]{2}{*}{ Datura } & Leaf & 43.66 & 52.44 & 48.05 \\
\hline & & (41.36) & $(46.40)$ & (43.88) \\
\hline \multirow[t]{2}{*}{ Alstonia } & Leaf & 31.41 & 42.41 & 36.91 \\
\hline & & $(34.09)$ & $(40.63)$ & (37.41) \\
\hline \multirow[t]{6}{*}{ Control } & - & 0.00 & 0.00 & - \\
\hline & & $(0.00)$ & $(0.00)$ & - \\
\hline & & SEm \pm & $\mathrm{CD}(\mathrm{p}=0.05)$ & \\
\hline & $\mathbf{P}$ & 0.35 & 1.01 & \\
\hline & Con. & 0.20 & 0.58 & \\
\hline & P x Con. & 0.57 & 1.64 & \\
\hline
\end{tabular}

*Average of four replications. Figures given in parentheses are angular transformed

Table.2 Efficacy of plant extracts against Alternaria leaf spot of lehsua (in vivo)

\begin{tabular}{|l|c|c|c|}
\hline $\begin{array}{l}\text { Common name of } \\
\text { plant }\end{array}$ & Dose & $\begin{array}{c}\text { Per cent disease } \\
\text { intensity* }\end{array}$ & $\begin{array}{c}\text { Per cent disease reduction over } \\
\text { control }\end{array}$ \\
\hline Garlic & 10 & 11.17 & 51.85 \\
\hline Neem & 10 & $(19.52)$ & 46.03 \\
\hline Ginger & 12.52 & 40.09 \\
\hline Datura & 10 & $(20.72)$ & 36.12 \\
\hline & 10 & $(21.89)$ & 28.10 \\
\hline Alstonia & 10.82 & \\
\hline & 10 & $(22.64)$ & \\
\hline Control & - & $(24.68$ & \\
\hline & & 23.20 & \\
\hline SEm \pm & & $(28.79)$ & \\
\hline CD $(\mathbf{p}=\mathbf{0 . 0 5})$ & & $\mathbf{0 . 4 7}$ & \\
\hline
\end{tabular}

* Average of four replications. Figures given in parentheses are angular transformed 
Table.3 Efficacy of fungicides on mycelial growth of Alternaria alternata at $7^{\text {th }}$ day of incubation at $25 \pm 1{ }^{\circ} \mathrm{C}$ (in vitro)

\begin{tabular}{|l|c|c|c|c|}
\hline \multirow{2}{*}{ Fungicide } & \multicolumn{3}{|c|}{ Per cent growth inhibition at various } & \multirow{2}{*}{ Mean } \\
\cline { 2 - 4 } & $\mathbf{1 0 0}$ & $\mathbf{3 0 0}$ & $\mathbf{5 0 0}$ & \\
\hline Mancozeb & 64.33 & 75.67 & 84.75 & $\mathbf{7 4 . 9 2}$ \\
\hline & $(53.33)$ & $(60.45)$ & $(67.01)$ & $\mathbf{( 5 9 . 9 4 )}$ \\
\hline Copper oxychloride & 66.69 & 78.81 & 88.64 & $\mathbf{7 8 . 0 5}$ \\
\hline Carbendazim + Mancozeb & $(54.75)$ & $(62.59)$ & $(70.30)$ & $\mathbf{( 6 2 . 0 6 )}$ \\
\hline & 68.75 & 77.00 & 87.17 & $\mathbf{7 7 . 6 4}$ \\
\hline Hexaconazole & $(56.01)$ & $(61.34)$ & $(69.01)$ & $\mathbf{( 6 1 . 7 8 )}$ \\
\hline & 91.14 & 95.56 & 98.61 & $\mathbf{9 5 . 1 0}$ \\
\hline Tebuconazole + Trifloxystrobin & $(72.68)$ & $(77.84)$ & $(83.23)$ & $\mathbf{( 7 7 . 2 2})$ \\
\hline & 96.20 & 100.00 & 100.00 & $\mathbf{9 8 . 7 3}$ \\
\hline Control & $(78.76)$ & $(90.00)$ & $(90.00)$ & $\mathbf{( 8 3 . 5 4})$ \\
\hline & 0.00 & 0.00 & 0.00 & \\
\hline & $(0.00)$ & $(0.00)$ & $(0.00)$ & \\
\hline & & $\mathbf{S E m} \pm$ & $\mathbf{C D}(\mathbf{p}=\mathbf{0 . 0 5})$ & \\
\hline & $\mathbf{F}$ & $\mathbf{0 . 6 1}$ & $\mathbf{1 . 7 3}$ & \\
\hline & $\mathbf{C}$ & $\mathbf{0 . 4 3}$ & $\mathbf{1 . 2 2}$ & \\
\hline & FxC & $\mathbf{1 . 2 2}$ & $\mathbf{3 . 4 6}$ & \\
\hline
\end{tabular}

*Average of 4 replications, Figures given in parentheses are angular transformed

Table.4 Efficacy of fungicides against Alternaria leaf spot of lehsua (in vivo)

\begin{tabular}{|l|c|c|c|}
\hline Fungicide & Dose & $\begin{array}{c}\text { Per cent } \\
\text { disease } \\
\text { intensity* }\end{array}$ & $\begin{array}{c}\text { Per cent disease } \\
\text { reduction over control }\end{array}$ \\
\hline Mancozeb & 0.25 & 8.71 & 60.10 \\
\hline Copper oxychloride & 0.25 & $(17.17)$ & 66.24 \\
\hline Carbendazim + Mancozeb & 0.20 & $(15.75)$ & 71.05 \\
\hline Hexaconazole & & $(14.56)$ & 74.58 \\
\hline Tebuconazole + Trifloxystrobin & 0.10 & 5.55 & 80.44 \\
\hline & 0.10 & $(13.63)$ & \\
\hline Control & & $(11.27$ & - \\
\hline & - & 21.83 & \\
\hline SEm $\mathbf{E}$ & & $(27.85)$ & \\
\hline CD $(\mathbf{p}=\mathbf{0 . 0 5})$ & & $\mathbf{0 . 2 9}$ & \\
\hline
\end{tabular}

* Average of four replications. Figures given in parentheses are angular transformed 
Fig.1 Efficacy of fungicides on mycelial growth of Alternaria alternata
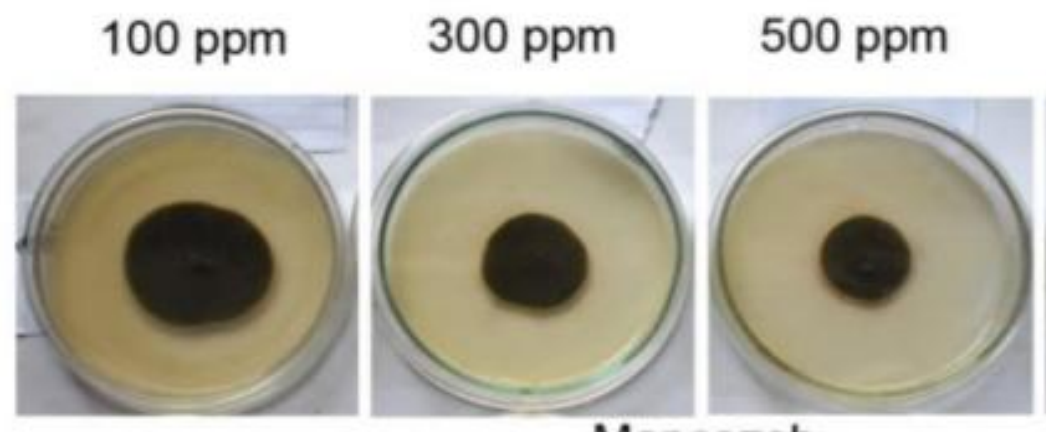

Control
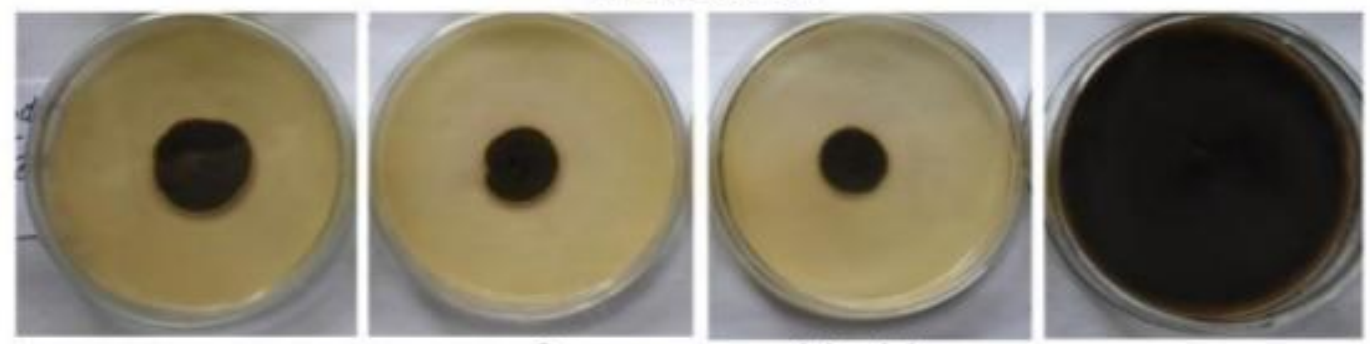

\section{Copper oxychloride}
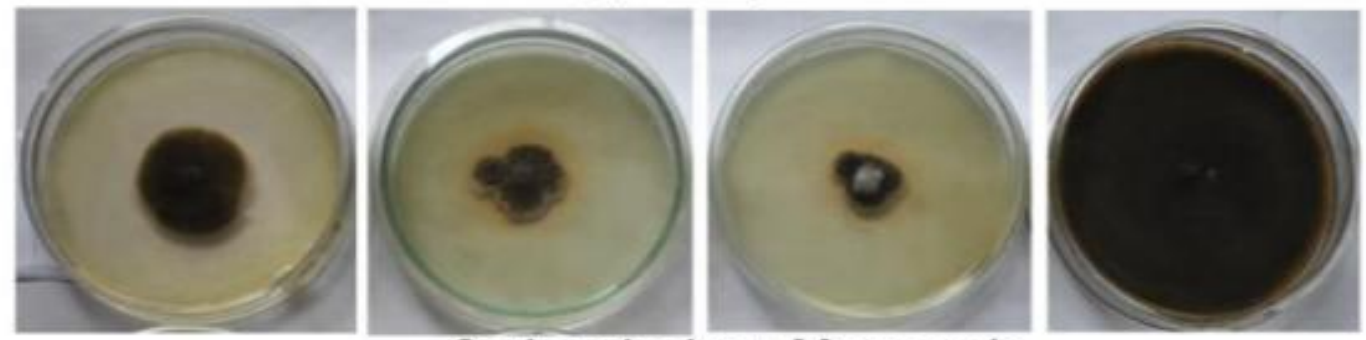

\section{Carbendazim + Mancozeb}
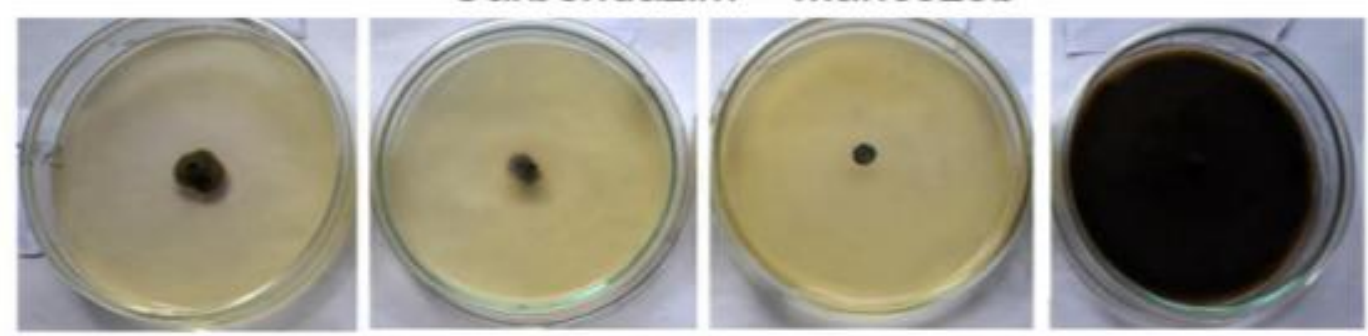

\section{Hexaconazole}
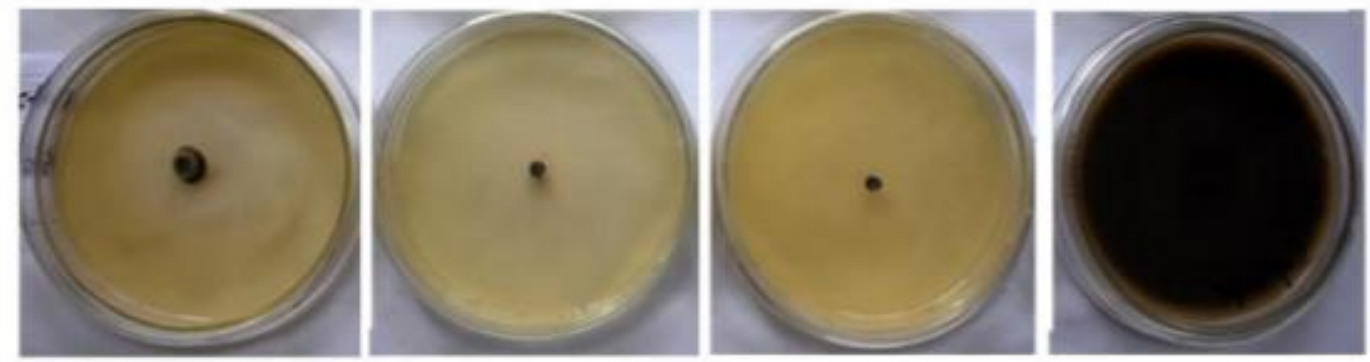

Tebuconazole + Trifloxystrobin 


\section{Fungicides}

The importance of chemicals cannot be denied in disease management. In lieu of this, the efficacy of five fungicides (Table 3) was tested in vitro at three concentrations viz. 100, 300 and 500 ppm against A. alternation PDA by Poisoned Food Technique. Among five fungicides, tebuconazole + trifloxystrobin was found most effective in inhibiting mycelial growth (96.20, 100 and $100 \%)$ of A. alternata at 100,300 and $500 \mathrm{ppm}$, respectively followed by hexaconazole $(91.14,95.56$ and 98.61\%) over control. Fungicides, carbendazim + mancozeb $(68.75,77.00$ and $87.17 \%)$, copper oxychloride $(66.69,78.81$ and $88.64 \%)$ and mancozeb $(64.33,75.67$ and $84.75 \%$ ) were found least effective in inhibiting mycelial growth over control. All the concentrations (100, 300 and $500 \mathrm{ppm}$ ) of tested fungicides were found significantly superior with each other except tebuconazole +trifloxystrobin at 300 and $500 \mathrm{ppm}$. Similar observations were also drawn by Kumar and Singh (1997), Kamble et al., (2000) and Rao and Rao (2002) while working with Alternaria spp. in vitro. They have reported that carbendazim, mancozeb, captan and copper oxychloride had inhibited the mycelial growth of the pathogen.

The results depicted in (Table 4) revealed that two sprays of all the fungicides at an interval of 20 days were found significantly superior over control in reducing disease intensity after 20 days of last spray. Minimum per cent disease intensity $(4.27 \%)$ was recorded with tebuconazole $\quad+\quad$ trifloxystrobin $(0.1 \%)$ followed by hexaconazole $(5.55 \%)$ and found at par with each other. Maximum disease control over check was also recorded with tebuconazole + trifloxystrobin (80.44\%) followed by hexaconazole (74.58\%) over control at $20^{\text {th }}$ day of last spray. Among these fungicides, the least effective in reducing per cent disease intensity was mancozeb
(60.10\%) followed by copper oxychloride $(66.24 \%)$. These observations are in line with those recorded by Rao and Rao (2002), Arun Kumar (2008), Meena et al., (2010) and Singh et al., (2016). Arun Kumar (2008) reported the effectiveness of hexaconazole $(0.1 \%)$ against leaf blight of chrysanthemum in a field. Chlorothalonil (Kavach 25 WP) and difenoconazole (Score 25 EC) @ 0.2 and 0.1 per cent concentrations respectively were found highly efficient in the management of Alternaria leaf blight of cluster bean. Meena et al., (2010) tried nine fungicides viz. mancozeb (Dithane M-45 75 WP, 0.2\%), zineb $(0.5 \%)$, carbendazim $2 \%+$ mancozeb $63 \%$ (Companion $65 \mathrm{WP}, 0.2 \%$ ), propineb (Antracol $70 \mathrm{WP}, 0.2 \%$ ), propiconazole (Tilt 25 EC, 0.1\%), hexaconazole (Contaf 5 EC, $0.1 \%$ ) and difenoconazole (Score $25 \mathrm{EC}$, $0.1 \%$ ) against Alternaria blight of clusterbean. They concluded that disease severity was low with chlorothalonil and difenoconazole. Singh et al., (2016) conducted an experiment for managing Alternaria leaf spot of ber. Out of seven treatments tried, maximum per cent disease control (77.33) was recorded with difenoconazole followed by propiconazole (75.00) and copper oxychloride (68.71) whereas neem oil (53.45) proved least effective. Maximum fruit yield/plant was recorded with difenoconazole $(92.00 \mathrm{~kg})$ followed by propiconazole $(89.50 \mathrm{~kg})$ and copper oxychloride $(80.00 \mathrm{~kg})$.

In conclusion, efficacy of above five systemic and non-systemic fungicides viz, tebuconazole +trifloxystrobin, hexaconazole, carbendazim + mancozeb, copper oxychloride and mencozeb tested by Poisoned Food Technique. Among these, tebuconazole + trifloxystrobinwas found most effective against Alternaria alternate followed by hexaconazole. While mencozeb was found least effective. Increase in concentration of fungicides was more effective in inhibiting the mycelial growth of the pathogen. In 
orchard, application of two sprays of tebuconazole + trifloxystrobin $(0.1 \%)$ at an interval of 20 days was found highly effective in controlling disease followed by hexaconazole against Alternaria alternata.

\section{References}

Anonymous. National Horticulture Production Database, Department of Horticulture, Pant Krishi Bhawan, 2017; Jaipur.

Anonymous. ICAR-All India Coordinated Research Project on Arid Zone Fruits, Bikaner, Rajasthan, 2017b; 187- 190.

Anonymous. ICAR-All India Coordinated Research Project on Arid Zone Fruits, Bikaner, Rajasthan, 2018; 199-200.

Badri ZA. Evaluation of fungitoxicants against Alternaria alternate causing umbel blight disease of kalazira (Bunium persicum). Indian Phytopathol. 2013; 66 (2): 195-196.

Chandra A, Chandra A. and Gupta IC. Arid Fruit Research.Scentific Publishers, Jodhpur.1994; 298-302.

Duhan A, Chauhan BM and Punia DC. Nutritional value of some non conventional plant foods of India. Plant Foods for Human Nutrition, 1992; 43(3): 193-200.

Kalieswari N, Raja I, Yesu and Devi M. Effect of fungicides on the mycelial growth ofAlternaria alternata causing leaf spot disease in ashwagandha. Inert. J. Pl. Protect. 2016; 9: 153-157.

Maurya S, Kumar R, Kumari A and
Choudhary JS. First reporte of Alternaria leaf blight in bael (Aegle marmelos (L.) Corr.) from Eastern Plateau and Hill Region of Inidia. $J$. Agri. Search, 2016; 3 (4): 248-250.

Mistry DS. Investigations of leaf spot [Alternaria alternata (Fr.) Keissler) and leaf blight (Drechslera hawaiensis Bough) disease of papaya. M.Sc. (Ag.) Thesis, agric. Univ., S.K. Nagar.1992; 27.

Rashmi and Yadav BP. A comparative efficacy of fungicides and plant extracts on radial growth and biomass production of Alternaria alternata. J. Appl. Biol. 1999; 9: 73-76.

Schimitzs H. A suggested toximetric method for wood preservation. Indus Engia. Chemistry Analysis Edition, 1930; 2: 361-363.

Singh $\mathrm{J}$ and Majumdar VL. Efficacy of plant extracts against Alternaria alternatathe incitant of fruit rot of pomegranate (Punica granatum L). J. Mycol. Pl. Pathol. 2001; 31(3): 346-349.

Singh S, Kumar S, Kumar Santosh and Tiwari PK. Epidemiology and management of Alternaria leaf spot (Alternaria alternata) of ber (Zizyphus mauritiana Lamk.). Res. Environ. Life Sci.2016; 9 (7):845-848.

Vincent JM. The esters of 4-hydroxyl benzoic acid and related compound. Methods for the study of their fungistatic properties. J. Sci. Indian, 1947; 16: 749-755.

\section{How to cite this article:}

Sushila Choudhary, R. P. Ghasolia, Manisha Shivran, Ramniwas Yadav and Vinod Bairwa. 2020. Management of Alternaria Leaf Spot of Lehsua through Plant Extracts and Fungicides. Int.J.Curr.Microbiol.App.Sci. 9(02): 2573-2580. doi: https://doi.org/10.20546/ijcmas.2020.902.293 